\title{
Multidirectional Lexical Borrowings in the Ancient Near East in the 2nd Millennium BC
}

\author{
By Marianna Pozza* \\ Valentina Gasbarra ${ }^{\dagger}$
}

\begin{abstract}
This paper investigates how Mycenaean Greek and Hittite languages can be analyzed in the light of the new acquisitions of historical sociolinguistics. In absence of living informants, the study of contact phenomena, which sheds light on a broader extra-linguistic scenario, could be an effective approach in a micro-sociolinguistic perspective. Particularly, the potential role played by Hittite as an intermediary between Akkadian and Mycenaean Greek will be analyzed. Interference phenomena seem to occur on two levels: on the one hand, there are lexemes directly borrowed from Hittite into Mycenaean while, on the other hand, we have found terms of a Semitic derivation where Hittite acts as an intermediary.
\end{abstract}

\section{Methodological Framework}

In the last few decades, the debate on the methodological, theoretical and practical implications of the complex relationship between language and society has been a major focus of linguistic research. This has spawned a number of important studies (for some recent and useful surveys, see: Coulmas, 1997; Ammon et al., 2006; Wardhaugh, 2006; Mesthrie, 2011) aiming not only to define the exact position of sociolinguistics among language sciences but also to identify its purpose, its areas of interest and the issues to be investigated.

The scope of sociolinguistic studies is the speaker who uses the language within a specific social and linguistic context. Problems arise when we try to apply these concepts and methods to the ancient world (Cipriano, D'Avino \& Di Giovine, 2000) and specifically to languages attested only through the mediation of writing (Molinelli, 1998, pp.411-415).

The use of sociolinguistic perspectives to explain languages of the past (whose attestation is often fragmentary and/or epigraphical) is virtually devoid of the possibility to engage in practical analysis. This consequently narrows the scope of the discipline as it makes it impossible or, at best, extremely hard to use a synchronic theoretical framework, where the evaluative attitude of the speaker and the socio-pragmatic context are fundamental (Mancini, 2012).

*Assistant Professor, University of Rome "La Sapienza", Italy.

†Post-Doctoral Fellow, University of Rome "La Sapienza", Italy. 
Labov's uniformitarian principle (Labov, 1975) has inspired a proliferation of methodological reflections regarding the relationship between sociolinguistics and historical linguistics. This has led to the establishment of a new disciplinary field, "historical sociolinguistics" (some useful surveys on historical sociolinguistics are found in: Conde-Silvestre, 2007; HernandezCampoy, \& Conde-Silvestre, 2012), sometimes referred to as "socio-historical linguistics" (definition essentially due to Romaine, 1982), the combined nature of which is located at the intersection of several disciplines such as linguistics, social sciences, and history.

From a sociolinguistic perspective, in relation to some irregular phonetic patterns of the Greek language, Brixhe (1979, pp.238-239) pointed out that unfortunately we know ancient languages only through the metalanguage of writing and we are therefore unable to know the real language community and its social structure.

Winter (1999) also emphasized the difficulty of making valid sociolinguistic arguments where extra-textual (i.e. extra-linguistic) data are scarcely available or absent. For this reason, he stated that 'conjectures one chooses to make tend to remain mere guesswork' (ibid., p.75). In this regard, sociolinguistic analysis strongly depends on the accessibility to a continuum of both linguistic and extra-linguistic information. If this is not the case, as in Labov's "invisible time" (Labov, 1994, p.73), we are faced with an imperfect framework, which can only be reconstructed through assumptions.

Even where it is possible to extend notions and terminology of modern sociolinguistics to ancient languages, their written nature - meaning preselective and strongly normalized documentary material - is a factor that could thwart the success of scientific research (for some remarkable examples, see Mancini, 2006; 2012). Epigraphical data, which are generally more relevant from a sociolinguistic point of view, must also be treated with caution (see the general remarks in Mancini, 2012).

Nonetheless, the sociolinguistic material inferable from corpus languages ${ }^{1}$, for which, as mentioned above, knowledge of the historical and social context is inevitably incomplete, may highlight some micro-phenomena which could serve to decode textual events and evaluate the direction of a change.

For this purpose, this paper shall analyze interference phenomena inferred from the documentary data in the Aegean-Anatolian area from a sociolinguistic point of view ${ }^{2}$.

\footnotetext{
${ }^{1}$ The definition of "corpus languages" instead of "classical languages", "dead languages" or "ancient languages" is adopted by Langslow (2002, pp.23-24) in order to avoid associations with the phenomenon of language death.

${ }^{2} \mathrm{~A}$ common pottery style of the Aegean-Anatolian Interface seems to be confirmed by archaeological studies (Cf. among others Mountjoy, 1998).
} 


\section{Linguistic Interference as an Instrument of Sociolinguistic Inquiry in Ancient Times}

Within sociolinguistic studies, an important distinction is made between macro- and micro-sociolinguistics (Cf. Berruto, 1974, pp.10; 83). Macrosociolinguistics deals with the analysis of systems within a community of speakers (i.e. the whole community and its varieties of code) whereas microsociolinguistics, on the contrary, focuses on individual events of communicative interaction, which is also referred to as 'face-to-face interaction' (Ammon et al., 2006, p.2) - the reference scale is represented by the communicative event and by speakers' verbal productions.

The boundaries of this distinction, however, can sometimes be blurred as it is also possible to identify some common subcategories. Fasold (1984; 1990), for example, suggested that when macro-sociolinguistics is framed within a sociological perspective, it tends to cover more general topics such as multilingualism as well as incorporating some micro-sociolinguistic phenomena such as the so-called "language attitudes". Conversely, microsociolinguistics stricto sensu tends to be connected with interactional dynamics (which include, for example, speech acts, ethnography of communication, but also some phenomena that, according to the interpretative approach, may pertain to both categories).

More generally, according to Coulmas's interpretation (1997, p.2), 'microsociolinguistics investigates how social structure influences the way people talk and how language varieties and patterns of use correlate with social attributes such as class, sex, and age. Macro-sociolinguistics, on the other hand, studies what societies do with their languages [...]'.

The inclusion of data from the Aegean-Anatolian documentation within this theoretical framework requires further elaboration: firstly, the reference scale, which is a common feature of all corpus languages, is not given by a community of "speakers" but by a community of "writers"; secondly, as pointed out above, what we know about the connection between social structure and real linguistic community is the result of reconstruction.

Data concerning the Aegean-Anatolian area have revealed the existence of some lexical loanwords resulting from language interference. These loanwords, in the light of what has been observed so far, should be placed within a microsociolinguistic frame as a result of "face to face interaction", where the writer records a phenomenon whose occurrence has been already attested by the community of speakers.

Due to the fragmentary nature and scarce usability of ancient languages for proper sociolinguistic inquiry, it should also be emphasised that, although recent handbooks deal with historical sociolinguistics, none of them deals with corpus languages, confirming the inadequacy of available data and achievable results.

The application of modern sociolinguistics criteria to ancient languages is at best problematic (cf. for example the interpretation of diastratic and stylistic varieties, considerably constrained and filtered by writing), this paper focuses 
attention on Aegean-Anatolian contact phenomena, which could be explained through the use of a sociolinguistic interpretative framework (we only mention here Weinreich, 1953; Gusmani, 1981; Thomason \& Kaufman, 1988). The multilingualism of many ancient societies could be better understood if analyzed from a sociolinguistic point of view, even in absence of a clear extralinguistic context (see also Schendl, 2012, p.530 ff.).

Another problem when dealing with genetically related languages attested in the $2^{\text {nd }}$ millennium $\mathrm{BC}$ is to evaluate whether terms believed to be contactinduced could be classified as loanwords or whether, on the contrary, they could be an indication of a common isogloss, thus showing some cognate elements.

In the first case, i.e. in the case of loanwords, we are dealing with an "externally motivated change" (cf. also Hickey, 2012), whose reasons must be sought in elements which are "external" to the language taken into examination. Moreover, when dealing with such ancient languages, it is not easy to assess the type of interference phenomena with certainty and thus identify convergence or divergence, as the case may be (cf. Conde-Silvestre, 2007, p.241 ff.).

Finally, in the case of some of the languages on which this paper focuses, Mycenaean Greek, Anatolian and Akkadian, the fragmented nature of the documentation is very often associated with a limited typology of texts, which restricts sociolinguistic analysis even more. To sum up, then, even if traditional sociolinguistic categories are potentially applicable in diachrony to ancient languages, the achieved results have to take into account a wide range of restrictions imposed by the field of investigation and, as a consequence, they should be accepted as largely hypothetical assumptions.

\section{Micro-sociolinguistic Phenomena in the Aegean-Anatolian Area: Some Case Studies}

\section{Direct Loanwords in Hittite and in Mycenaean Greek}

In the reproduction of a "foreign" term we can recognize the more advanced outcome of a contact situation. This can happen out of necessity, for example in a changed cultural context, but also for reasons due to the prestige of an interfering language: these are the two key points addressed by Bloomfield's distinction between "cultural borrowings" and "prestige borrowings" (Bloomfield, 1933, p.458 ff.).

Interference phenomena are always associated with the concept of bilingualism. However, two languages may interact without necessarily assuming that the speakers or those communities are bilingual; sometimes, there might just be some relationship between different communities, like when, for example, a language is present in a community who speaks a different language.

The existence of loanwords "at distance", i.e. not directly depending on bilingualism, is also well observed in many modern European languages 
(Weinreich, 2011, p.53). This can be easily applied to the Aegean-Anatolian world. Despite some explanatory attempts, there is not any direct evidence of effective bilingualism; however, there is information of some language elements in different directions, where the writer consciously or unconsciously chooses to code-switch (for the theory about the presence of Anatolian scribes acting as "interpreters" in Mycenaean palaces, see Bryce, 1999; 2003b, pp.7677 , and the relevant bibliography).

Within a typology of documentation seen in Hittite and Mycenaean archives, code-switching can be attributed to several items ${ }^{1}$ and it can be assumed to relate to the economy and trade.

It is always difficult to separate proper loanwords from wandering words (Kultur- or Wanderwörter). Whether in the presence of loanwords or of Wanderwörter, the micro-sociolinguistic data gathered draw a highly heterogeneous picture, with several languages (not always genetically related) interacting and acting, in turn, as model or borrowing language. This corroborates the impression that all these phenomena attested for in written documentation are the direct consequence of a face to face interaction realised by speakers.

The presence of direct loanwords ${ }^{2}$ is widely attested for; also, it should be pointed out that Hittite and Akkadian can either be the model or the borrowing language. In the first typology (e.g. Hittite as a model language), the following examples can be listed: Hitt. arkamma(n) 'tribute' and upati- 'landed property, concession', from which Akkad. argamannu 'purple' and ubadinnu, the name of a landed concession donated to the king dignitaries. In the second typology (e.g. Akkadian as a model language), we can include examples like Hitt. LÚ apiši 'exorcist, enchanter (Babilonian)', Hitt. ${ }^{\text {LÚ }}$ kumra- (designation of a religious officer), Hitt. halzi- 'fortress', Hitt. zuppari- 'torch' for which the Akkadian correspondent, āšipu(m), kumru(m), halșu(m) and tiparu(m) respectively, represents the model word. The category of direct loanwords includes also terms with uncertain etymology and/or meaning: Hitt. magareš 'coppery things', probably a loanword from Akkad. magarru 'wheel'; the adverb (URU) pabilili 'in Babylonian, in Akkadian', a loanword from Akkad. bābilu 'Babylon'; lastly, (TƯG/GAD) $\operatorname{lupan}(n) i$-/luwanni- 'headgear, hairband, diadem', '(sword)-knob', maybe from Akkad. (TÚG/GADA) lubāru 'linen garment'.

As discussed before, more difficulties arise when evaluating wandering words, due to their ambiguous etymology and to the lack of the original word. Within this category, we can include terms like Hitt. kipriti- 'a kind of bird' or 'a kind of mineral', probably connected with Akkad. kibrītu 'dark sulphur' or with Akkad. kibru- 'riverbank' (with a reference to the sulphurous waters of

\footnotetext{
${ }^{1}$ In Langslow's work (2002), see the reference to Fishman, Cooper \& Ma (1971), who identify in the following 5 items the motivation of the code-switching: "family, friendship, religion, employment and education".

${ }^{2}$ For further remarks about Greek-Anatolian interference phenomena during the $2^{\text {nd }}$ millennium BC, see Gasbarra \& Pozza (2012); for those between Akkadian and Hittite, see Dardano (2011).
} 
the river Tigris) as well as a wide range of names of minerals, materials and plants: Hitt. nitri- 'bicarbonate' from Akkad. nit(i)ru id.; Hitt. zapzagi- 'glass', from Akkad. zabzabgĥ '(a kind of) glaze'; Hitt. allantaru- 'wood of allānu', 'oak', probably from Akkad. allānu(m) 'oak' (?); Hitt. kappani- 'cumin' (see

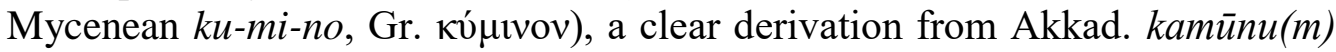
or kamannu(m), as well as šapšama- 'sesame', from Akkad. šamaššammū $(m)$ id.

There are also terms borrowed from Akkadian through the intermediation of the Hurrian language: Hitt. pühugari- 'alternative, substitute, replacement' from Akkad. $p \bar{u} h u$ 'substitute'; Hitt. api- 'sacrificial grave' from Akkad. apu-; Hitt. '́ $a p u z z i-$ 'warehouse' from Akkad. abūsu 'storage'; Hitt. (TÚG) adupli'ceremony dress, cloak, belt' probably from Akkad. utuplu; Hitt. huratti'attention, supervision' from Akkad. hurādu id.; Hitt. makalti-, magalzi-, makanti- 'farinaceous', 'bowl' from Akkad. mākaltu- '(wooden) bowl' (for a close examination, see Pozza, 2011).

The identification of terms borrowed from Akkadian is also possible for the very limited Mycenaean documentation, for example: ku-mi-no-(a), Gr.

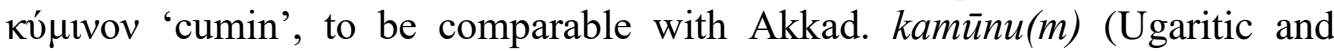

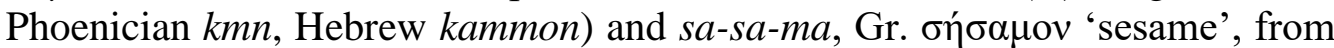
Akkad. šamaššammū $(m)$ (Ugaritic and Phoenician $\check{s} s m n$ ). The name of the aromatic and decorative plant 'cyperus' has a more uncertain Semitic origin: Mycenean ku-pa-ro and Gr. кú $\pi \alpha$ ipov, whose model could be the Hebrew word koper, however connected with another kind of plant, 'cyprus' Gr. кú $\pi \rho \circ$ s.

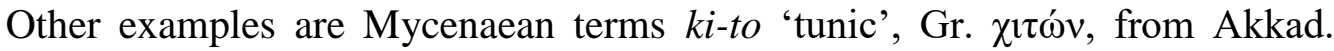
kitû( $m$ ) (Ugaritic and Phoenician ktn, Hebrew kutonet), borrowed from

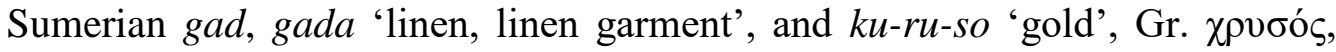
from Akkad. hurāșu(m) (Ugaritic and Phoenician hrrș, Hebrew ḩārūṣ).

Finally, the Mycenaean hapax ka-ti can be interpreted, in the light of the context where it appears, with the name of a vase or a jar, connected with Gr. ${ }^{*} \kappa \bar{\alpha} \theta$ ís (cfr. $\kappa \eta \theta i ́ \varsigma$ ), allotrope of Gr. $\kappa \alpha ́ \delta o \zeta$. The term $k a-t i$ is generally considered a loanword from the Semitic $k d$, attested in several dialects, Ugaritic and Phoenician $k d$, Hebrew $k a d$, and with the same meaning of 'vase, holder for liquid substance'.

\section{Mediated Loanwords in Hittite and in Mycenaean Greek}

Notoriously, one of the most complex and debated issues central to defining the chronological framework of the ancient Near East in the $2^{\text {nd }}$ millennium $\mathrm{BC}$ is to determine with certainty the migratory movements and the precise geographical location of populations of Anatolia in prehistoric times (cf. recently Yakubovich, 2008, to whom we also refer for a summary of the different opinions about the geographical origin of the Anatolian populations and for its rich bibliography).

If, for example, one considers the different assumptions about the exact geographical location of Luwian speakers in the $2^{\text {nd }}$ millennium BC, the view that the Luwians occupied the South-Western territories of the Anatolian peninsula (among the others, Bryce, 2003a) and that they expanded eastward 
contrasts with the view according to which the original geographical location of the Luwian populations should be based more towards the East (cf. particularly Yakubovich, 2008).

From a sociolinguistic point of view, especially according to the principle of mutual intelligibility (Dixon, 1997), which is unfortunately difficult to apply to dead languages, both Hittite and Luwian should actually be considered as fully-fledged languages. In particular, as amply demonstrated by Yakubovich (2010), Luwian, which is closely related to Hittite - deriving from a common ancestor -, was surely perceived as a separate language, not as a dialect of Hittite.

On the one hand, the gradual proliferation of Luwian glosses in more recent Hittite texts seems to suggest a growing Luwian-Hittite bilingualism in the capital Hattuša; on the other, it cannot be excluded that the two languages coexisted in a diglossic relationship, with Hittite representing the high variety and Luwian the low one (see in particular van den Hout, 2007). Using the words of Yakubovich (2010, p. 409), the bilingual code-switching observable in late Hittite texts could be interpreted as 'convenience-driven rather than solidarity-driven'.

In fact, although the term "Hittite" refers to a substantially unitary entity from a political perspective, it does not actually relate to a well defined and equally uniform cultural and linguistic entity. The Hittite language is strongly influenced by substrate and/or adstrate languages (cf. in particular Melchert, 2003, pp.21-22) such as Hattic, Luwian and Hurrian (an Asian language which played a very important role as a mediator between Akkadian and Hittite). This proves that there was an established multilingual pattern typical of the Anatolian peninsula in the $2^{\text {nd }}$ millennium BC.

Still, a great influence was exerted by Akkadian, the official language of diplomacy from which Hittite derives - with some adaptations - its graphic cuneiform system and by Sumerian, which, as well as being the first model for the graphic system of ancient Near Eastern languages, continues to exert its influence and be the object of written compositions even after its death as a spoken language, maintaining a crucial ideological function for the formation of the scribal and intellectual identity of that time (for the different opinions about the time of the death of Sumerian as a spoken language and its relationship with Akkadian, we refer to the discussion in Woods, 2007, and the related references).

Finally, in the geo-linguistic landscape of this area in the $2^{\text {nd }}$ millennium $\mathrm{BC}$, it is important to mention the Mycenaean Greek connexion, which was chronologically contemporary with the Indo-European and non-Indo-European languages of Anatolia and Mesopotamia and geographically adjacent to the Western shores of the Anatolian peninsula.

The areal contiguity between the languages under scrutiny and the mutual trade and cultural exchanges should be considered as a favourable basis for linguistic interference: therefore, the relative homogeneity of the cultural and archaeological facies of the Aegean-Anatolian area would not seem necessarily due (see Gusmani, 1968) to the existence of a common cultural and ethnic 
background, although both linguistic interference and a common substrate are not necessarily irreconcilable.

All these factors, only briefly discussed here, could help to identify a potentially optimal sociolinguistic field of investigation ${ }^{1}$, if only we did not have to deal with the difficulties of corpus languages.

Apart from cases of interference occurring in individual speech acts (which, in the cases discussed here, are only conceivable as ongoing phenomena), it is a well known fact that the place of contact is represented by the same individuals who use the language. It is also equally true that, if we actually want to speak of a real contact, linguistic innovation has to spread from the single speaker to the community out of necessity or due to the prestige of the terms offered by the model language, as shown in the examples below.

As noted above (see pp.248-250), for example, in Mycenaean Greek many words of Semitic origin are documented, reflecting the importance that the model language, i.e. Akkadian, had in the $2^{\text {nd }}$ millennium BC. Some of these words, sometimes interpreted as Wanderwörter, seem to have undergone the intermediation of Hittite, which appears to have played the role of "bridging language" between a non-Indo-European language such as Akkadian and an Indo-European language such as Mycenaean Greek.

It is useful to mention, for instance, the Mycenaean words $k u$-wa-no 'lapis lazuli' (cf. Hitt. $k u(w a) n n a(n)$ - and Akkad. uqnû(m)), ku]-pe-ra '(a type of) pot' (cf. Hitt. kukupalla, Akkad. kukubu) and e-re-pa 'ivory' (cf. Hitt. lahpa-, Akkad. $\operatorname{alpu}(m)$ 'ox'), whose formal structure reflects, according to what has been suggested elsewhere, the mediating role played by Hittite (for further details concerning also Greek-Anatolian contacts during the $1^{\text {st }}$ millennium BC, cf. Gasbarra \& Pozza, 2012; 2013).

Similarly, in the Hittite language, it is possible to find cases of Akkadian loans which, in their turn, are modelled on foreign words, especially Sumerian: Akkadian seems to have been the intermediary between Sumerian and Hittite; see, for example, Akkad. lahannu- 'drinking cup' with respect to the likely Sumerian pattern ${ }^{\mathrm{DUG}}$ lahan 'bottle, container used in rituals' and the Hittite counterpart lahanni- 'bottle' (where, as usual, it is also possible to recognize a Hurrian intermediation); Hitt. kirinni- 'precious stone', from Akkad. girinnu, borrowed from Sum. girin; Hitt. ummiyanni- '(name of a) priest', from Akkad. ummeānu-, borrowed from Sum. ummea; Hitt. 'Ĺ́ šankunni- 'priest', through Hurrian intermediation, from Akkad. $\check{s} a n g \hat{u}(m)$ id., in turn likely to have been borrowed from Sum. sanga; Hitt. tuppi- 'clay tablet', again via Hurrian, from Akkad. tuppu(m)/tuppu $(m)$ 'clay tablet, letter, document', which in turn was borrowed from Sum. dub id .

We shall not dwell on the subject, as the formal reasons why it would be possible to imagine such a process have already been described and discussed elsewhere (Gasbarra \& Pozza, 2012; 2013). The review presented above, however, clearly shows that Akkadian, because of its wide official and diplomatic use and its role as an "international" language, could well represent

${ }^{1}$ For an overview of the linguistic contacts between $2^{\text {nd }}$ and $1^{\text {st }}$ millennium $B C$ in the framework of multilingual Anatolia, see the essays in Cotticelli Kurras et al. (2012). 
the linguistic medium through which Sumerian words became part of the Hittite lexicon. Sumerian and Akkadian speakers, in fact, coexisted for centuries in the area south of Babylon. This, of course, in addition to promoting a significant impact on each of the two languages, generated a growing bilingualism among Sumerian speakers, especially during the Third Dynasty of Ur.

\section{Conclusions}

This work aims at evaluating interference phenomena (both Kultur- or Wanderwörter and lexical borrowings with their relative adaptation phenomena) in the Aegean-Anatolian area during the $2^{\text {nd }}$ millennium $\mathrm{BC}$ as sociolinguistic items, with special reference to micro-sociolinguistics.

The results emerged from a close examination of data, with all the necessary caution that this type of documents implies, have made it possible to identify a set of multidirectional lexical borrowing patterns within the framework of the ancient Near East and its cultural and linguistic melting pot. Thanks to the sociolinguistic perspective adopted in this work, data have been classified using chronotopic variables, which, if well defined - as recently shown by Silvestri (2013) - can help trace the routes of the borrowing procedure.

In our opinion, when dealing with ancient languages like Hittite or Mycenaean and, generally speaking, with languages whose extra-linguistic context is almost unknown, the primary focus must be on contact-induced change. This is, we believe, the only reasonable sociolinguistic approach that can be used to shed light on the migration of words whose success has already been decreed by the community of speakers.

\section{Figures}

The following figures include the lexemes quoted in: Direct Loanwords in Hittite and in Mycenaean Greek and Mediated Loanwords in Hittite and in Mycenaean Greek. 
Figure 1. Direct Loanwords in Akkadian and in Hittite

\begin{tabular}{|c|c|}
\hline \multicolumn{2}{|l|}{ Hittite $\rightarrow$ Akkadian } \\
\hline $\operatorname{arkamma}(n)$ 'tribute' & argamannu 'purple' \\
\hline upati- 'landed property, concession' & $\begin{array}{l}\text { ubadinnu (name of a landed concession } \\
\text { donated to the king dignitaries) }\end{array}$ \\
\hline \multicolumn{2}{|l|}{ Akkadian $\rightarrow$ Hittite } \\
\hline$\overline{a s ̌ i p u(m) ~ ' e x o r c i s t ' ~}$ & ${ }^{\mathrm{LU}}$ apiši 'exorcist, enchanter (Babilonian)' \\
\hline kumru $(m)$ 'priest' & $\begin{array}{l}{ }^{\mathrm{L}} \begin{array}{l}\text { kumra- } \\
\text { officer) }\end{array} \\
\text { (designation of a religious }\end{array}$ \\
\hline halsu $(m)$ 'fortress, district' & halzi-'fortress' \\
\hline $\operatorname{tiparu}(m)$ 'torch' & zuppari- 'torch' \\
\hline magarru'wheel' & magareš 'coppery things' \\
\hline bābilu 'Babylon' & (URU) pabilili 'in Babylonian, in Akkadian' \\
\hline (TÚG/GADA) lubāru 'linen garment' & $\begin{array}{l}\text { (TUG/GAD) lupan }(n) i-/ l u w a n n i- \\
\text { hairband, diadem' }\end{array}$ \\
\hline kibru- 'riverbank' & kipriti- 'a kind of bird/mineral'" \\
\hline nit(i)ru 'bicarbonate' & nitri- 'bicarbonate' \\
\hline zabzabgûu '(a kind of) glaze' & zapzagi- 'glass' \\
\hline $\operatorname{allānu}(m)$ 'oak' & allantaru- 'wood of allānu', 'oak' \\
\hline \multicolumn{2}{|c|}{ Akkadian $\rightarrow$ Hittite (Hurrian intermediation) } \\
\hline$p \bar{u} h u$ 'substitute' & $\begin{array}{l}\text { pühugari- } \\
\text { replacement' }\end{array}$ 'alternative, substitute, \\
\hline$a p u$ - 'hole, opening' & api- 'sacrificial grave' \\
\hline$a b \bar{u} s u$ 'storage' & Eapuzzi- 'warehouse' \\
\hline utuplu 'scarf, shawl (?)' & (TUG) adupli- 'ceremony dress, cloak, belt' \\
\hline hurāà 'attention, supervision' & huratti- 'attention, supervision' \\
\hline mākaltu- '(wooden) bowl' & 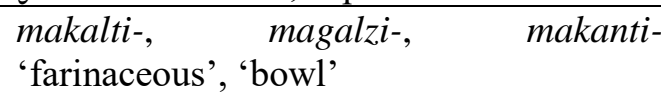 \\
\hline
\end{tabular}

Figure 2. Akkadian/Hittite/Mycenaean/Greek direct Loanwords

\begin{tabular}{|c|c|c|c|}
\hline Akkadian & Hittite & Mycenaean & Greek \\
\hline $\begin{array}{l}\text { kamūnu(m)/kamannu(m) } \\
\text { 'cumin' }\end{array}$ & kappani- 'cumin' & $\begin{array}{l}\text { ku-mi-no- }(a) \\
\text { 'cumin' }\end{array}$ & 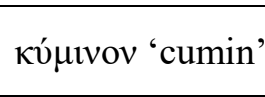 \\
\hline šamaššammū $(m)$ 'sesame' & $\begin{array}{l}\text { šapšama- } \\
\text { 'sesame' }\end{array}$ & $\begin{array}{l}\text { sa-sa-ma } \\
\text { 'sesame' }\end{array}$ & $\begin{array}{l}\sigma \eta ́ \sigma \alpha \mu o v \\
\text { 'sesame' }\end{array}$ \\
\hline kitûu(m) 'linen garment' & - & ki-to 'tunic' & $\chi \imath \tau \omega ́ v$ 'tunic' \\
\hline hurāșu(m) 'gold' & - & ku-ru-so 'gold' & 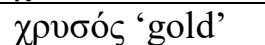 \\
\hline
\end{tabular}

Figure 3. Mediated Loanwords in Hittite and in Mycenaean Greek

\begin{tabular}{|c|c|c|}
\hline \multicolumn{3}{|c|}{$\begin{array}{l}\text { Model language (Akkadian) } \rightarrow \text { Bridging language (Hittite) } \rightarrow \text { Borrowing } \\
\text { language (Mycenaean) }\end{array}$} \\
\hline$u q n \hat{u}(m)$ 'lapis lazuli' & $k u(w a) n n a(n)-$ 'lapis lazuli' & 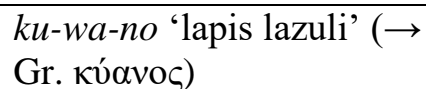 \\
\hline$k u k u b u$ '(a type of) pot' & kukupalla'(a type of) pot' & 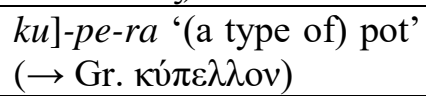 \\
\hline $\operatorname{alpu}(m)$ 'ox' & lahpa- 'ivory' & $\begin{array}{l}e-r e-p a \\
\dot{\varepsilon} \lambda \dot{\varepsilon} \varphi \alpha \varsigma)\end{array}$ \\
\hline
\end{tabular}




\begin{tabular}{|c|c|c|}
\hline \multicolumn{3}{|c|}{$\begin{array}{l}\text { Model language (Sumerian) } \rightarrow \text { Bridging language (Akkadian) } \rightarrow \text { Borrowing } \\
\text { language (Hittite) }\end{array}$} \\
\hline $\begin{array}{l}\text { DUG lahan 'bottle, } \\
\text { container used in rituals'" }\end{array}$ & lahannu- 'drinking cup' & lahanni- 'bottle' \\
\hline girin 'precious stone' & girinnu 'precious stone' & kirinni- 'precious stone' \\
\hline $\begin{array}{l}\text { ummea '(name of a) } \\
\text { priest' }\end{array}$ & $\begin{array}{l}\text { ummeānu- '(name of a) } \\
\text { priest' }\end{array}$ & $\begin{array}{l}\text { ummiyanni- '(name of a) } \\
\text { priest' }\end{array}$ \\
\hline sanga 'priest' & 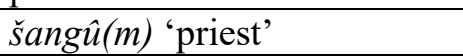 & ${ }^{\mathrm{L}}{ }^{\mathrm{S}}$ šnkunni- 'priest' \\
\hline $\begin{array}{l}\text { dub 'clay tablet, letter, } \\
\text { document' }\end{array}$ & $\begin{array}{l}\text { tuppu }(m) / \text { tuppu }(m) \\
\text { tablet, letter, document' }\end{array}$ & tuppi- 'clay tablet' \\
\hline
\end{tabular}

\section{Acknowledgements}

This paper is a product of the PRIN project "Linguistic representations of identity. Sociolinguistic models and historical linguistics", coordinated by P. Molinelli (PRIN 2010/2011, prot. 2010HXPFF2, sponsored by the Italian Ministry of Education and Research). This paper represents the result of a regular and fruitful collaboration among the two authors. The following division is only for academic purposes: V. Gasbarra Methodological Framework and Linguistic Interference as an Instrument of Sociolinguistic Inquiry in Ancient Times; M. Pozza Micro-sociolinguistic Phenomena in the Aegean-Anatolian Area: Some Case Studies (Direct Loanwords in Hittite and in Mycenaean Greek and Mediated Loanwords in Hittite and in Mycenaean Greek); both authors Conclusions.

\section{References}

Ammon, et al. eds., 2006. Sociolinguistics. An International Handbook of Science Language and Society. 2nd ed. Berlin and New York: De Gruyter.

Berruto, G., 1974. Sociolinguistica. Bologna: Zanichelli.

Bloomfield, L., 1933. Language, New York: Holt, Rinehart and Winston.

Brixhe, C., 1979. Sociolinguistique et langues anciennes. Bulletin de la Société de Linguistique de Paris 74, pp.237-259.

Bryce, T., 1999. Anatolian Scribes in Mycenaean Greece. Historia. Zeitschrift für alte Geschichte 48, pp.257-264.

Bryce, T., 2003a. History. In: H.C. Melchert, ed., The Luwians. Leiden and Boston: Brill, pp.27-127.

Bryce, T. 2003b. Relations between Hatti and Ahhiyawa in the Last Decades of the Bronze Age. In: G. Beckman, R. Beal, \& G. Mac Mahon, eds., Hittite Studies in Honour of Harry A. Hoffner Jr. on the Occasion of his 65th Birthday. Winona Lake, Indiana: Eisenbrauns, pp.59-72.

Cipriano, P., D'Avino, R. \& Di Giovine, P., eds., 2000. Linguistica storica e sociolinguistica. Roma: Il Calamo.

Conde-Silvestre, J.C., 2007. Sociolingüística histórica. Madrid: Gredos. 
Cotticelli Kurras, P., et al., eds., 2012. Interferenze linguistiche e contatti culturali in Anatolia tra II e I millennio a.C. Studi in onore di Onofrio Carruba in occasione del suo $80^{\circ}$ compleanno. Genova: Italian University Press.

Coulmas, F., 1997. The Handbook of Sociolinguistics. Oxford (UK) and Cambridge (MA): Blackwell.

Dardano, P., 2011. Mehrsprachigkeit im hethitischen Reich: Die Beziehungen zwischen dem Hethitischen und dem Akkadischen. In: D. Boschung \& C.M. Riehl, eds. Historische Mehrsprachigkeit. Workshop des Zentrums für Antike Kulturen des Mittelmeerraums und des Zentrums Sprachenvielfalt und Mehrsprachigkeit an der Universität Köln, 4.-5. Juli 2008, Aachen: Shaker Verlag, pp.47-59.

Dixon, R.M.W., 1997. The Rise and Fall of Languages. Cambridge: Cambride University Press.

Fasold, R., 1984. The Sociolinguistics of Society. Oxford (UK) and Cambridge (MA): Backwell.

Fasold, R., 1990. The Sociolinguistics of Language. Oxford: Blackwell.

Fishman, J.A., Cooper, L.R. \& Ma, R., 1971. Bilingualism in the Barrio. New York: Indiana University Press.

Gasbarra, V. \& Pozza, M., 2012. Fenomeni di interferenza greco-anatolica nel II millennio a.C.: l'ittito come mediatore tra mondo indoeuropeo e mondo non indoeuropeo. Annali dell'Istituto Orientale di Napoli N.S. 1, pp.165-214.

Gasbarra, V. \& Pozza, M., 2013. Pluralità di vie del prestito: i casi di itt. lahanni- gr.

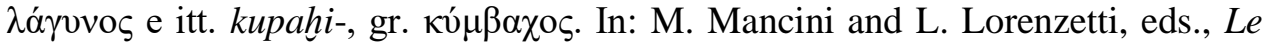
lingue del Mediterraneo antico. Culture, mutamenti, contatti. Roma: Carocci, pp.181-191.

Gusmani, R., 1981. Saggi sull'interferenza linguistica. Firenze: Le Lettere.

Hernandez-Campoy, J.M. \& Conde-Silvestre, J.C., 2012, eds. The Handbook of Historical Sociolinguistics. Oxford: Blackwell.

Hickey, R., 2012. Internally- and Externally-Motivated Language Change. In: J.M. Hernandez-Campoy and J.C. Conde-Silvestre, eds. The Handbook of Historical Sociolinguistics. Oxford: Blackwell, pp.387-406.

Labov, W., 1975. On the Use of the Present to Explain the Past. In: L. Heilman, ed. In: Proceedings of the $11^{\text {th }}$ International Congress of Linguists, Bologna 1972. Bologna: Il Mulino, pp.825-851.

Labov, W., 1994. Principles of Linguistic Change, 1, Internal Factors. Oxford (UK) and Cambridge (MA): Blackwell.

Langslow, D.R., 2002. Approaching Bilingualism in Corpus Language. In: J.N. Adams, M. Janse S. \& Swain, eds., Bilingualism in Ancient Societies. Oxford: Oxford University Press, pp.23-51.

Mancini, M., 2006, Dilatandis litteris: uno studio su Cicerone e la pronunzia 'rustica'. In: R. Bombi, et al., eds. Studi linguistici in onore di Roberto Gusmani. Alessandria: Edizioni dell'Orso, pp.1023-1046.

Mancini, M., 2012. Su alcune questioni di metodo in sociolinguistica storica: le defixiones sannite. In: V. Orioles, ed., Per Roberto Gusmani. Linguistica storica e teorica. Studi in ricordo. Udine: Forum, pp.239-271.

Melchert, H.C., 2003. The Luwians. Leiden and Boston: Brill.

Mesthrie, R. ed, 2011. The Cambridge Handbook of Sociolinguistics. Cambridge: Cambridge University Press.

Molinelli, P., 1998. Premesse metodologiche per una sociolinguistica del latino. In: G. Bernini, P. Cuzzolin \& P. Molinelli, P. eds. Ars linguistica. Studi offerti a Paolo Ramat in occasione del suo 60 compleanno. Roma: Bulzoni, pp.411-433. 
Mountjoy, P.A., 1998. The East Aegean-West Anatolian Interface in the Late Bronze Age: Mycenaeans and the Kingdom of Ahhiyawa. Anatolian Studies 48, pp.3367.

Pozza, M., 2011. La grafia delle occlusive intervocaliche in ittito. Verso una riformulazione della lex Sturtevant. Roma: Il Calamo.

Romaine, S., 1982. Socio-Historical Linguistics. Its Status and Methodology. Cambridge: Cambridge University Press.

Schendl, H., 2012. Multilingualism, Code-Switching, and Language Contact in Historical Socio-Linguistics. In: J.M. Hernandez-Campoy \& J.C. CondeSilvestre, eds. The Handbook of Historical Sociolinguistics. Oxford: Blackwell, pp.520-533.

Silvestri, D., 2013. Interferenze linguistiche nell'Egeo tra presitoria e protostoria. In: M. Mancini \& L. Lorenzetti, Le lingue del Mediterraneo antico. Culture, mutamenti, contatti. Roma: Carocci, pp.333-375.

Thomason, S.G. \& Kaufman, T., 1988. Language Contact, Creolization and Genetic Linguistics. Berkeley: University of California Press.

Van den Hout, T., 2007. Institutions, Vernaculars, Public: The Case of Second Millennium Anatolia, 2nd ed. In: S. Sanders, ed. Margins of Writing, Origins of Cultures. New Approaches to Writing and Reading in the Ancient Near East. Chicago: McNaughton and Gunn, pp.221-262.

Wardhaugh, R., 2006. An Introduction to Sociolinguistics. 5th ed. Oxford: Blackwell.

Weinreich, U., 1953. Languages in Contact. New-York.

Weinreich, U., 2011. Languages in Contact. French, German and Romansh in the Twenthieth-Century in Switzerland. With an Introduction and Notes by Ronald I. Kim and William Labov. Amsterdam: Benjamins.

Winter, W., 1999. Sociolinguistics and Dead Languages. In: E.H. Jahr, ed. Language Change. Advances in Historical Sociolinguistics. Berlin and New York: Mouton de Gruyter, pp.67-84.

Woods, C., 2007. Bilingualism, Scribal Learning, and the Death of Sumerian. $2^{\text {nd }}$ ed. In: S. Sanders, ed., Margins of Writing, Origins of Cultures. New Approaches to Writing and Reading in the Ancient Near East. Chicago: McNaughton and Gunn, pp.95-124.

Yakubovich, I., 2008. Luwian Migrations in Light of Linguistic Contacts. In: B.J. Collins, M.R. Bachvarova \& I.C. Rutherford, eds. Anatolian Interfaces. Hittites, Greeks and Their Neighbours. Oxford: Oxbow, pp.123-134.

Yakubovich, I., 2010. Sociolinguistics of the Luwian Language. Leiden and Boston: Brill. 
